\title{
Synthesis and Structural Characterization of a Novel Thulium-Nickel Heterobimetallic Complex $\left\{(\mathrm{DMF})_{10} \mathrm{Tm}_{2}\left[\mathrm{Ni}(\mathrm{CN})_{4}\right]_{3}\right\}_{\infty}$
}

\author{
Sang Mock Lee, ${ }^{\dagger}$ Hongrae Kim, Jungho Park, An-Soo Kang ${ }^{\ddagger}$ Sang-Bong Moon, ${ }^{\S}$ \\ Sang Hern Kim, ${ }^{*}$ Sheldon G. Shore, ${ }^{\text {s.* }}$ and Jang-Hoon Chung ${ }^{*}$ \\ Department of Chemisty' Myongi University: Yongin 449-728, Korea. "E-mail: changihaninac.kr \\ ${ }^{\dagger}$ Materials Center, Samsung Advanced Institute of Technology; Yongin 446-712, Korea \\ ${ }^{\ddagger}$ Department of Chemical Engineering, Myongii University; Yongin 449-728, Korea \\ ${ }^{8}$ Elchem Tech Co., Seoul 153-803, Korea \\ ${ }^{2}$ Department of Applied Chemisty, Hanbat National University, Daejeon 305-719, Korea \\ 'Deparment of Chemistry, The Ohio State University, Columbus, OH43210, U.S.A. "E-mail. shore.I@osu.edu \\ Received March 6, 2008
}

Key Words : Thulium-Nickel heterobimetallic complex, One dimensional array, Bridging cyanide

The heterobimetallic complexes containing electropositive and labile lanthanide and transition metals have been desirable for heterogeneous and homogeneous catalytic studies. ${ }^{1,2}$ While direct lanthanide-transition metal bonds are ideal for such a purpose, their syntheses can be very challenging. ${ }^{3}$ The complexes with bridging ligands are much more accessible. ${ }^{+}$Therefore, our focus has been to synthesize the complexes containing the cyanide anion as a bridging ligand between lanthanide cations and the transition metals which might serve as precursors to bimetallic catalysts on oxide surfaces. ${ }^{5}$ The bidentate character of two of the four cyanides in $\left[\mathrm{M}(\mathrm{CN})_{4}\right]^{2-}$ has shown various types of structures in the solid state ${ }^{+6}$ Recently, we have reported $\operatorname{Tm}(\mathrm{III})$ $\mathrm{M}$ heterobimetallic complexes of the type $(\mathrm{DMF})_{1 i} \mathrm{Tm}_{1-}$ $\left.\left[\mathrm{M}(\mathrm{CN})_{4}\right]_{3}\right\}_{\infty}(\mathrm{M}=\mathrm{Pt}, \mathrm{Pd} ; \mathrm{DMF}=\mathrm{N}, \mathrm{N}$-dimethyl formamide) in which Tm(III) ions are bridged by the bidentate $\mathrm{M}(\mathrm{CN})_{4}{ }^{2-}$ anions. ${ }^{7.8}$ The present study is concerned with the completion of the synthesis of a series of the group VIII transition metal system containing cyanide-bridged lanthanide-transition metal arrays.

Described here is detail of the synthesis and crystal structure of a novel one dimensional array $\mathrm{Tm}(\mathrm{III})-\mathrm{Ni}$ heterobimetallic complex $\left\{(\mathrm{DMF})_{1 j} \mathrm{Tm}_{2}\left[\mathrm{Ni}(\mathrm{CX})_{4}\right]_{3}\right\}_{0}$ prepared quantitatively in the reaction of $\mathrm{TmCl}_{3}$ and $\mathrm{K}_{2} \mathrm{Ni}(\mathrm{CN})_{4}(2: 3$ molar ratio). The structure of the complex consists of two $\mathrm{Tm}$ (III) ions bridged by two bidentate $\mathrm{Ni}(\mathrm{CN})_{4}{ }^{2-}$ anions in a cis fashion, generating a $\mathrm{Tm}_{2} \mathrm{Ni}_{2}$ metal core.

\section{Experimental Section}

General procedures. All manipulations were carried out on a standard high vacuum line or in a drybox under an atmosphere of dry, $99.99 \%$ pure nitrogen. Dimethyl formamide (DMF; Aldrich) was stirred over pretreated $4 \AA$ molecular sieves (Aldrich) for 4 days. The DMF was distilled into a $500 \mathrm{~mL}$ flask and then stored in the drybox for future use. $\mathrm{TmCl}_{3}$ was purchased from Aldrich and used as received. $\mathrm{K}_{2}\left[\mathrm{Ni}(\mathrm{CN})_{4}\right] \cdot 3 \mathrm{H}_{2} \mathrm{O}$ (Aldrich) was dried under vacuum at $200^{\circ} \mathrm{C}$ for $1 \mathrm{~h}$ and stored in the drybox. Fourier transform infrared (FT-IR) spectra were recorded on a Mattson Polaris Fourier transform spectrometer with $2 \mathrm{~cm}^{-1}$ resolution. Elemental analysis was performed by Galbraith Laboratories, Inc., Knoxville, Tr.

X-ray structural characterization. A single crystal of $\left\{(\mathrm{DMF})_{10} \mathrm{Tm}_{2}\left[\mathrm{Ni}(\mathrm{CN})_{4}\right]_{3}\right\}$ was mounted on the tip of a glass fiber coated with Fomblin oil (Aldrich). Single crystal $\mathrm{X}$-ray diffraction data were collected on an Enraf-Nonius Kappa-CCD diffraction system, which employs graphite monochromated Mo $\mathrm{K} \alpha$ radiation $(\lambda=0.71073 \AA)$. Unit cell parameters were obtained by indexing the peaks in the first 10 frames and refined employing the whole data set. Data integration was carried out for Lorentz and polarization effects using the Denzo-SMN package (Nonius BV, 1999)." The absorption corrections were applied using the SORTAV program ${ }^{10}$ provided by MaXus software. ${ }^{10}$ The structure was solved by direct methods and refined using SHELXL-97 (difference electron density calculations and full matrix least-squares refinements) structure solution package. ${ }^{12}$

Preparation of $\left\{(\mathrm{DMF})_{10} \mathrm{Tm}_{2}\left[\mathrm{Ni}(\mathrm{CN})_{4}\right]_{3}\right\}$. A $50 \mathrm{~mL}$ flask was charged with $275.3 \mathrm{mg}(1.0 \mathrm{mmol})$ of $\mathrm{TmCl}_{3}$ and a magnetic stirring bar in the drybox. Then $25 \mathrm{~mL}$ of DMF was pipetted into the flask. To this solution was added 361.4 $\mathrm{mg}(1.5 \mathrm{mmol})$ of $\mathrm{K}_{2} \mathrm{Ni}(\mathrm{CN})_{4}$ and the flask was sealed with a fine-fritted vacuum line extractor. After all reactants were dissolved in DMF, the mixture was stirred at room temperature for 4 days. During the process the solution turned cloudy due to the formation of $\mathrm{KCl}$. The precipitate was removed by filtration, and the pale yellow filtrate was reduced in volume for crystallization. X-ray quality single crystals formed during dynamic vacuum in a day. Yield: nearly quantitative. IR ( $\left.\mathrm{KBr}, v_{\mathrm{cN}}, \mathrm{cm}^{-1}\right) 2163$ (s), 2152 (s), 2125 (s); Anal. Caled for $\mathrm{C}_{42} \mathrm{H}_{70} \mathrm{~N}_{22} \mathrm{O}_{10} \mathrm{Ni}_{3} \mathrm{Tm}_{2}: \mathrm{C}, 32.39 ; \mathrm{H}$, $4.53 ; \mathrm{N}, 19.79$. Found: C, $28.68 ; \mathrm{H}, 4.03 ; \mathrm{N}, 18.87$.

\section{Results and Discussion}

One dimensional array with the general formula $(\mathrm{DMF})_{1(1-}$ $\left.\operatorname{Tm}_{2}\left[\mathrm{Ni}(\mathrm{CN})_{4}\right]_{3}\right\}$ was obtained via metathesis reaction of 
Table 1. Crystallographic Data for $\left\{(\mathrm{DMF})_{10} \operatorname{Tm} \cdot\left[\mathrm{Ni}(\mathrm{CN})_{4}\right]_{3}\right\}_{*}$

\begin{tabular}{|c|c|}
\hline empirical fomula & $\mathrm{C}_{42} \mathrm{H}_{31,} \mathrm{~N}_{2 \leq 2} \mathrm{Ni}_{3} \mathrm{O}_{11,} \mathrm{~T}_{\mathrm{m}}$ \\
\hline fw & 1557.19 \\
\hline space group & $\mathrm{Pi}$ \\
\hline a. $\AA$ & $10.2909(2)$ \\
\hline b. $\AA$ & $10.9452(2)$ \\
\hline$\therefore \AA$ & $15.0452(3)$ \\
\hline$\alpha, \operatorname{deg}$ & $73.978(1)$ \\
\hline$\beta$, deg & $83.963(1)$ \\
\hline$\gamma, \operatorname{deg}$ & $83.828(1)$ \\
\hline$V, \AA^{3}$ & $1614.30(5)$ \\
\hline Z & 1 \\
\hline$\rho\left(\right.$ calcd), $\mathrm{mg} / \mathrm{m}^{3}$ & 1.602 \\
\hline $\mathrm{T}, \mathrm{K}$ & $150(2)$ \\
\hline$\lambda, \AA$ & Mo K $\alpha(0.71073)$ \\
\hline$\theta$ range (deg) & $2.67-27.46$ \\
\hline$h k l$ ranges & $\begin{array}{l}-1313,-1414 \\
-1919\end{array}$ \\
\hline Reflections collected & 43745 \\
\hline Independent reflections & 7384 \\
\hline$\mu, \operatorname{mum}^{-1}$ & 3.642 \\
\hline GOF & 1.049 \\
\hline$R_{\mathrm{J}}[\mathrm{I}>2 \sigma(\mathrm{I})]^{* t}$ & 0.0279 \\
\hline$w R_{\Sigma}(\text { all data })^{h}$ & 0.0502 \\
\hline
\end{tabular}

2:3 molar ratio of $\mathrm{TmCl}$, with $\mathrm{K}_{2 \mathrm{Ni}} \mathrm{Ni}(\mathrm{CN})_{4}$ in $\mathrm{DMF}$ at room temperature (eq. 1). To ensure complete removal

$2 \mathrm{TmCl}_{3}-3 \mathrm{~K}_{2} \mathrm{Ni}(\mathrm{CN})_{4} \stackrel{\mathrm{DMF}}{\longrightarrow}\left\{(\mathrm{DMF})_{15} \mathrm{Tm} \cdot\left[\mathrm{Ni}(\mathrm{CN})_{4}\right]:\right\}_{3}-6 \mathrm{KCl}$

of chloride as $\mathrm{KCl}$, long reaction time such as 4 days was employed. The required long metathesis reaction time was in part due to the stability of the inner-sphere coordination complex. ${ }^{13}$ The low solubility of $\mathrm{TmCl}_{3}$ in DMF also contributed to the long reaction time.

Crystallographic data and selected bond distances and angles for $\left\{(\mathrm{DMF})_{10} \mathrm{Tm}_{2}\left[\mathrm{Ni}(\mathrm{CN})_{4}\right]_{3}\right\}_{\alpha}$ are listed in Tables 1 and 2 , respectively. This structure is different from those of $\mathrm{Tm}-\mathrm{Pd}$ and Tm-Pt systems. ${ }^{7,8}$ The structure consists of an unique nonisostructural one-dimensional array which is consistent with $\mathrm{Yb}-\mathrm{Ni}$ heterobimetal complex $(\mathrm{DMF})_{10^{-}}$ $\left.\mathrm{Yb}_{2}\left[\mathrm{Ni}(\mathrm{CN})_{4}\right]_{3}\right\}_{x_{2}}{ }^{5 / 23}$ The two structures, types I and II in
Table 2. Selected Bond Distances ( $A$ ) and Angles (deg)

\begin{tabular}{ll}
\multicolumn{1}{c}{ Bond Distances } & \\
$\mathrm{Tm}-\mathrm{O}(1) 2.2884(18)$ & $\mathrm{Tm}-\mathrm{O}(2) 2.344(2)$ \\
$\mathrm{Tm}-\mathrm{O}(3) 2.288(2)$ & $\mathrm{Tm}-\mathrm{O}(4) 2.314(2)$ \\
$\mathrm{Tm}-\mathrm{O}(5) 2.304(2)$ & $\mathrm{Tm}-\mathrm{N}(6) 2.450(2)$ \\
$\mathrm{Tm}-\mathrm{N}(8) 2.432(2)$ & $\mathrm{Tm}-\mathrm{N}(11) 2.416(2)$ \\
$\mathrm{Ni}(1)-\mathrm{C}(16) 1.866(3)$ & $\mathrm{Ni}(1)-\mathrm{C}(17) 1.871(3)$ \\
$\mathrm{Ni}(2)-\mathrm{C}(18) 1.870(3)$ & $\mathrm{Ni}(2)-\mathrm{C}(19) 1.873(3)$ \\
$\mathrm{Ni}(2)-\mathrm{C}(20) 1.872(3)$ & $\mathrm{Ni}(2)-\mathrm{C}(21) 1.860(3)$ \\
& \\
$\mathrm{C}(16)-\mathrm{Ni}(1)-\mathrm{C}(16 \mathrm{~b})$ & $180.000(0)$ \\
$\mathrm{C}(16)-\mathrm{Ni}(1)-\mathrm{C}(17 \mathrm{~b})$ & $88.85(12)$ \\
$\mathrm{C}(18)-\mathrm{Ni}(2)-\mathrm{C}(21 \mathrm{a})$ & $91.34(11)$ \\
$\mathrm{C}(18)-\mathrm{Ni}(2)-\mathrm{C}(20)$ & $176.94(13)$ \\
$\mathrm{C}(18)-\mathrm{Ni}(2)-\mathrm{C}(19)$ & $89.16(12)$ \\
$\mathrm{C}(16)-\mathrm{N}(6)-\mathrm{Tm}$ & $177.0(2)$ \\
$\mathrm{C}(21)-\mathrm{N}(11)-\mathrm{Tm}$ & $168.7(2)$ \\
$\mathrm{N}(9)-\mathrm{C}(19)-\mathrm{Ni}(2)$ & $177.0(3)$ \\
$\mathrm{N}(11)-\mathrm{C}(21 \mathrm{a})-\mathrm{Ni}(2)$ & $174.1(3)$ \\
$\mathrm{C}(16)-\mathrm{Ni}(1)-\mathrm{C}(17)$ & $91.15(12)$ \\
$\mathrm{C}(17)-\mathrm{Ni}(1)-\mathrm{C}(17 \mathrm{~b})$ & $180.000(10)$ \\
$\mathrm{C}(20)-\mathrm{Ni}(2)-\mathrm{C}(21 \mathrm{a})$ & $89.19(12)$ \\
$\mathrm{C}(19)-\mathrm{Ni}(2)-\mathrm{C}(21)$ & $172.81(14)$ \\
$\mathrm{C}(19)-\mathrm{Ni}(2)-\mathrm{C}(20)$ & $90.69(13)$ \\
$\mathrm{C}(18)-\mathrm{N}(8)-\mathrm{Tm}$ & $174.4(2)$ \\
$\mathrm{N}(8)-\mathrm{C}(18)-\mathrm{Ni}(2)$ & $177.5(2)$ \\
$\mathrm{N}(10)-\mathrm{C}(20)-\mathrm{Ni}(2)$ & $178.5(3)$ \\
\hline & \\
&
\end{tabular}

Scheme 1, result from the differences in coordination of the ligands to the $\operatorname{Tm}(\mathrm{III})$ ions. This complex adopts the structural type II in which the one dimensional array is generated by translating the repeating unit along the ac diagonals of the lattice. Two $\mathrm{Tm}(\mathrm{III})$ ions are bridged by two $\mathrm{Xi}(\mathrm{CN})_{4}{ }^{2-}$ anions in a cis fashion, creating diamond-shaped $\mathrm{Tm}_{2} \mathrm{Ni}_{2}$ metal cores that are held together by cyanide bridges. These cores are then linked by $\mathrm{Ni}(\mathrm{CN})_{4}{ }^{2-}$ anions which are bound to the thulium atoms through cynide bridges in a trans fashion. Unlike this complex, Tm-Pt and Tm-Pd complexes $\left\{(\mathrm{DMF})_{10} \operatorname{Tm}_{2}\left[\mathrm{M}\left(\mathrm{CN}_{4}\right)_{3}\right\}_{\sigma}(\mathrm{M}=\mathrm{Pt}, \mathrm{Pd}\}^{7.8}\right.$ adopt the structural type $\mathrm{I}$ in which the repeating units are translated only along the crystallographic $a$ axis of the lattice. The structures consist of two parallel running zigzag chains that are inverted from each other. The chain are then connected through the $\mathrm{Tm}$ atoms by trans bridging $\mathrm{M}(\mathrm{CN})_{+}{ }^{2-}(\mathrm{M}=\mathrm{Pt}, \mathrm{Pd})$

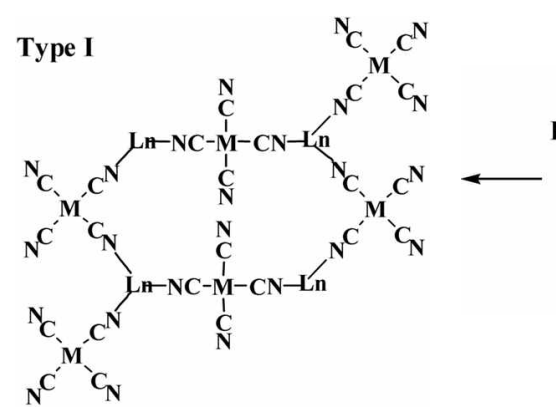

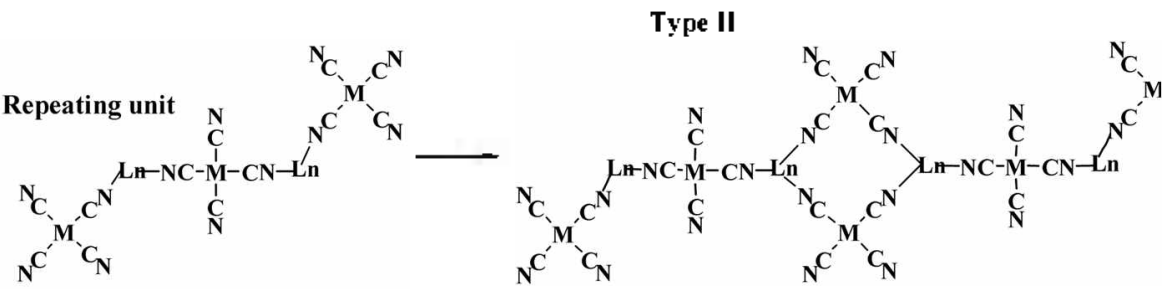


(a)

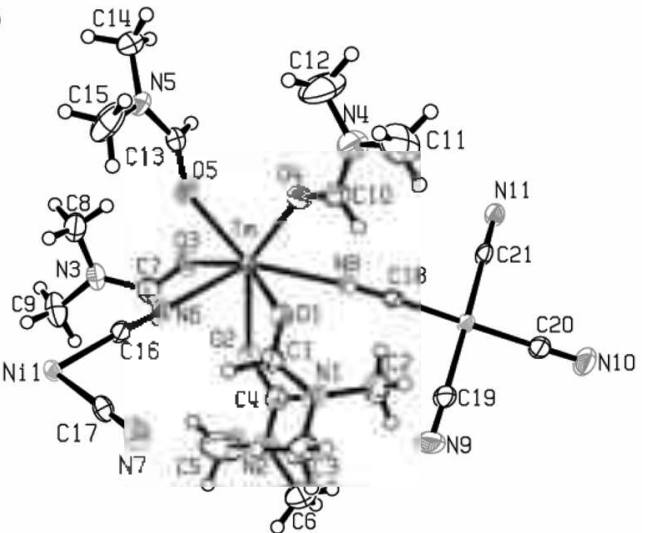

(b)

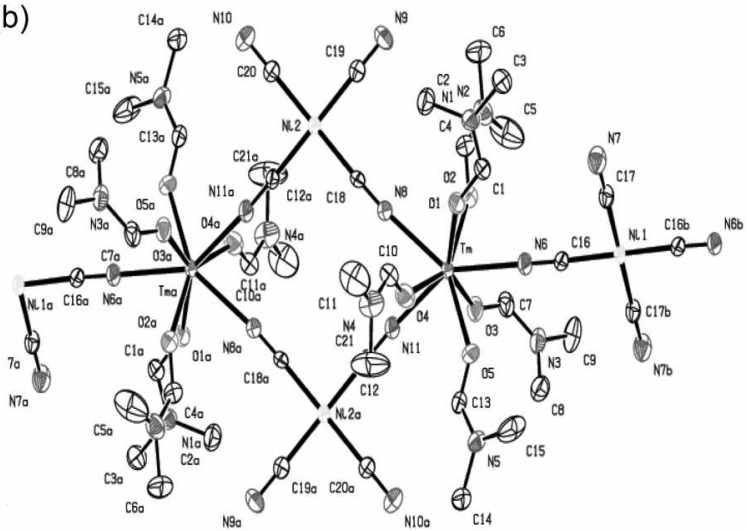

Figure 1. One dimensional structure (50\% themmal ellipsoids) of $\left\{(\mathrm{DMF})_{10} \mathrm{Tm}_{2}\left[\mathrm{Ni}(\mathrm{CN})_{4}\right]_{3}\right\} \%$, (a) Coordination geometry around thulium atom. (b) A portion of one dimensional array.

anions.

The coordination around Tm atom governs the structural type adopted for the complex array. ${ }^{14}$ In the structure of TmNi complex (Figure 1), $\mathrm{Tm}(\mathrm{III})$ ions are bound to three $\mathrm{N}$ atoms of the bridging cyanide ions and five $\mathrm{O}$ atoms of the DMF ligands. The coordination geometry around each of the thulium atoms is a slightly distorted square antiprism. Two of the coordinated $\mathrm{N}$ atoms share an edge of one of the bases of the antiprism, while the third $\mathrm{N}$ atom occupies a corner of the other base opposite the shared edge. The edge sharing $N$ atoms, $N(8)$ and $N(11)$ of the square antiprism are donated by two cyanide ligands of two cis bridges $\mathrm{Ni}(\mathrm{CN})_{4}{ }^{2-}$ anions. while the third $\mathrm{N}$ atom, $\mathrm{N}(6)$ is from a cyanide ligand of a trans bridge $\mathrm{Ni}(\mathrm{CX})_{4}{ }^{2-}$ anion. The average $\mathrm{Tm}-\mathrm{N}$ and $\mathrm{Tm}-\mathrm{O}$ bond distances for the eight coordinate $\mathrm{Tm}$ (III) ion in the complex are 2.433 and $2.308 \AA$, respectively. These average distances are comparable to those observed in $\mathrm{Tm}-\mathrm{Pd}, \mathrm{Tm}-$ $\mathrm{Pt}$ and other lanthanide metal systems. ${ }^{78,1+}$ The coordination geometry around the nickel atom is approximately square planar. The widest $\mathrm{C}-\mathrm{Ni}-\mathrm{C}$ bond angle $\left(91.33^{\circ}\right)$ in the structure is $\mathrm{C}(18)-\mathrm{Ni}(2)-\mathrm{C}(21 \mathrm{a})$ that bridges two sterically crowded thulium atoms in a cis fashion, while the bond angle $\mathrm{C}(16)-\mathrm{Ni}(1)-\mathrm{C}(17)$ bridging in a trans tashion is $91.15^{\circ}$. Though the $\mathrm{C}(18)-\mathrm{Ni}(2)-\mathrm{C}(21 \mathrm{a})$ is opened to bridge two thulium atoms, this does not affect the linearity of the

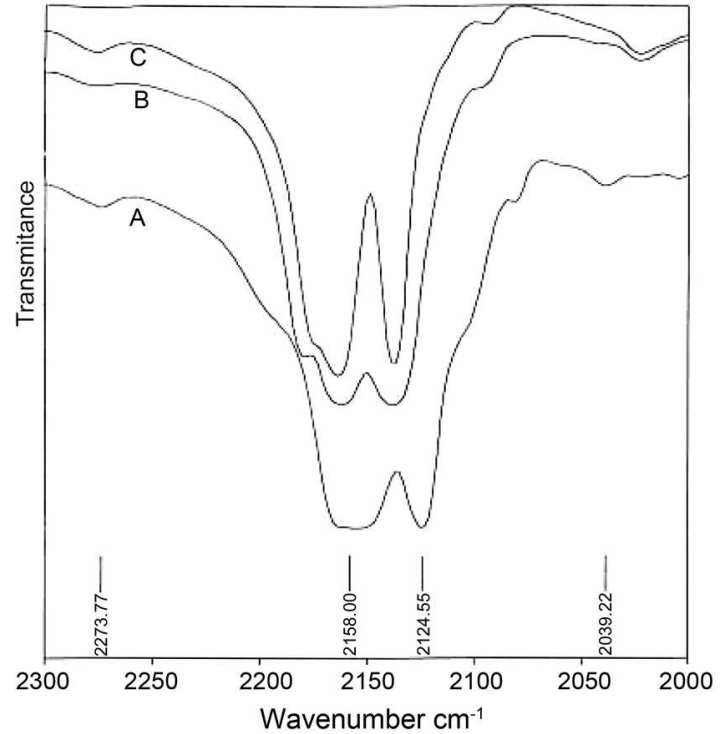

Figure 2. Solid state infrared spectra of one dimensional arrays: A. $\left\{(\mathrm{DMF})_{10} \mathrm{Tm}_{2}\left[\mathrm{Ni}(\mathrm{CN})_{4}\right]_{3}\right\} \quad$ B. $\left.\quad(\mathrm{DMF})_{10} \mathrm{Tm}_{2}\left[\mathrm{Pd}(\mathrm{CN})_{4}\right]_{3}\right\} \%$ $\left\{(\mathrm{DMF})_{10} \mathrm{Tm}_{2}\left[\mathrm{Pt}(\mathrm{CN})_{4}\right]_{3}\right\} \%$.

$\mathrm{Ni}-\mathrm{C}-\mathrm{N}$ bond angles ranging from 174.0 to $178.5^{\circ}$. On the contrary, C-N-Tm bond angles vary with regard to linearity ranging from 168.7 to $177.0^{\circ}$ due to steric crowding around the thulium atoms. The distances between $\mathrm{H}$ atoms of the methyls and $\mathrm{N}$ atoms of the $\mathrm{CN}$ bridges or $\mathrm{O}$ atoms of DMFs and the D-H-A bond angles shown in Table 3 suggest that there exist the hydrogen bond interactions. ${ }^{15}$ The $\mathrm{H}^{\cdots} \mathrm{N}$ and $\mathrm{H} \cdots \mathrm{O}$ interatomic distances range 2.55 to $2.59 \AA$ and 2.35 to $2.60 \AA$, respectively and the $\mathrm{C}-\mathrm{H} \cdots \mathrm{N}$ and $\mathrm{C}-\mathrm{H} \cdots \mathrm{O}$ angles range 146.3 to $167.2^{\circ}$ and 100.2 to $105.9^{\circ}$, respectively.

The experimental section lists the observed infrared absorption frequencies for the complex. Solid-state infrared spectra are useful in distinguishing between type I and type II structure. The stretching pattems in the infrared spectrum (Figure 2) of $\left\{(\mathrm{DMF})_{10} \operatorname{Tm}_{2}\left[\mathrm{Ni}(\mathrm{CN})_{4}\right]_{3}\right\}_{\sigma}=$ with structural type II differs from those of $\left\{(\mathrm{DMF})_{10} \operatorname{Tm}_{2}\left[\mathrm{Pd}(\mathrm{CN}\}_{4}\right]_{3}\right\}_{x}$, and $\left\{(\mathrm{DMF})_{10} \operatorname{Tm}_{2}\left[\mathrm{Pt}\left(\mathrm{CN}_{4}\right)_{3}\right\}_{3}\right\}_{\infty}$ with structural type I. The spectrum $\mathrm{A}$ of $\left\{(\mathrm{DMF})_{10} \mathrm{Tm}_{2}\left[\mathrm{Ni}(\mathrm{CN})_{4}\right]_{3}\right\}_{x}$ consists of three absorptions at 2163 (s), 2152 (s), and 2125 (s) $\mathrm{cm}^{-1}$. The

Table 3. Selected Bond Distances $(\AA)$ and Angles (deg, $D=$ Donor, $\mathrm{A}=$ Acceptor)

\begin{tabular}{lcccc}
\hline $\mathrm{D}-\mathrm{H} \cdots \mathrm{A}$ & $\mathrm{d}(\mathrm{D}-\mathrm{H})$ & $\mathrm{d}\left(\mathrm{H}^{\cdots} \mathrm{A}\right)$ & $\mathrm{d}(\mathrm{D} \cdots \mathrm{A})$ & $<(\mathrm{DHA})$ \\
\hline $\mathrm{C}(2)-\mathrm{H}(2 \mathrm{~A}) \cdots \mathrm{O}(1)$ & 0.98 & 2.35 & $2.767(4)$ & 104.8 \\
$\mathrm{C}(3)-\mathrm{H}(3 \mathrm{~A}) \cdots \mathrm{N}(7)$ & 0.98 & 2.58 & $3.539(4)$ & 167.2 \\
$\mathrm{C}(6)-\mathrm{H}(6 \mathrm{~A}) \cdots \mathrm{N}(9)$ & 0.98 & 2.56 & $3.421(5)$ & 146.3 \\
$\mathrm{C}(8)-\mathrm{H}(8 \mathrm{~A}) \cdots \mathrm{N}(7)+\dot{H} 2$ & 0.98 & 2.59 & $3.467(4)$ & 149.0 \\
$\mathrm{C}(8)-\mathrm{H}(8 \mathrm{C}) \cdots \mathrm{O}(3)$ & 0.98 & 2.38 & $2.789(4)$ & 104.5 \\
$\mathrm{C}(10)-\mathrm{H}(10) \cdots \mathrm{O}(1)$ & 0.95 & 2.60 & $2.999(4)$ & 105.9 \\
$\mathrm{C}(12)-\mathrm{H}(12 \mathrm{~A}) \cdots \mathrm{O}(4)$ & 0.98 & 2.39 & $2.736(5)$ & 100.2 \\
$\mathrm{C}(14)-\mathrm{H}(14 \mathrm{~B}) \cdots \mathrm{N}(7)+{ }_{H} 3$ & 0.98 & 2.55 & $3.503(5)$ & 164.9 \\
$\mathrm{C}(15)-\mathrm{H}(15 \mathrm{~A}) \cdots \mathrm{O}(5)$ & 0.98 & 2.38 & $2.777(4)$ & 103.6 \\
\hline
\end{tabular}

Symmetry transformations used to generate equivalent atoms: $\$ 1-x$.

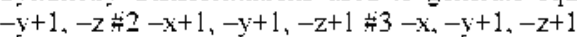


infrared spectra for type II complex contain bands that are higher than the normal modes for the cyanide ligand in $\mathrm{K}_{2}\left[\mathrm{Ni}(\mathrm{CN})_{4}\right]\left(2127 \mathrm{~cm}^{-1}\right){ }^{16}$ Typically bridging $\mathrm{CX}$ ligands have higher stretching frequencies than the terminal $\mathrm{Cr}^{\mathrm{T}}$ ligands. ${ }^{17}$ Accordingly, cyanide stretching bands $(2163,2152$ $\mathrm{cm}^{-1}$ ) at higher frequencies than the stretching modes of $\mathrm{K}_{2}\left[\mathrm{Ni}(\mathrm{CN})_{4}\right]$ are assigned to bridging cyanide ligands. The band at $2125 \mathrm{~cm}^{-1}$ is assigned to terminal cyanide ligands because their location in the cyanide stretching region compares with the absorptions observed for the nonbridging cyanide ligands in $\mathrm{K}_{2}\left[\mathrm{Ni}\left(\mathrm{Cr}_{4}\right)_{4}\right]$. Array $\left\{(\mathrm{DMF})_{10} \mathrm{Tm}_{2}-\right.$ $\left.\left[\mathrm{Ni}(\mathrm{CN})_{4}\right]_{3}\right\}_{\infty}$ and other lanthanide metal-Ni systems display similar $\mathrm{CN}$ stretching patterns in their spectra. ${ }^{14}$

Supplementary Material. Crystallographic data for structural analysis have been deposited with the Cambridge Crystallographic Data Center (CCDC No. 668539). Copy of this information may be obtained free of charge from The Director, CCDC, 12 Union Road, Cambridge CB2 1EZ, UK (Fax: +44-1223-336033; e-mail: deposit a cedc.cam.ac.uk or www: http:/ www.ccde.cam.ac.uk).

Acknowledgments. This work was supported by the Hydrogen Energy R\&D Center, one of the 21st Century Frontier R\&D Program, funded by the Ministry of Science and Technology of Korea. We thank Dr. Judith Gallucei in the Department of Chemistry of The Ohio State University for providing the crystal structure results.

\section{References}

1. (a) Imamura, H.; Miura, Y; Fujita, K.; Sakata, Y; Tsuchiya, S. $J$. Mol. Catd. A 1999, 140, 81. (b) Imamura, H.; Igawa, K.; Sakata, Y.; Tsuchiya, S. Bull. Chem. Soc. Jph. 1996, 69, 325.
2. Huskens, I.; Peters, I. A.; van Bekkum, H.; Choppin, G. R. Inorg. Chent. 1995, 34, 1756 .

3. (a) Beletskaya, I. P.; Voskoboynikov, A. Z.; Chuklanova, E. B.; Kirillova, N. I.; Shestakova, A. K.; Parshina, 1. N.; Gusev, A. I.; Magomedov, G K.-I. J. Am. Chem. Soc. 1993, 115, 3156. (b) Deng, H.; Chun, S.; Florian, P.; Grandinetti, P. J.; Shore, S. G. Inorg. Chen. 1996, 35, 3891 .

4. (a) Cernak, J.; Potocnak, I.; Chomic, J.; Dunaj-Jurco, M. Acto Cristallogr: 1990, C46, 1098. (b) Yuge, H.; Iwamoto, T. Acta Cristallogr: 1995, C51, 374 .

5. (a) White, J. P., III; Deng, H. B.; Boyd, E. P.; Gallucci, J.; Shore, S. G. Inorg. Chem 1994, 33, 1685. (b) Deng, H. B.; Shore, S. G. $J$. An. Chem. Soc. 1991, $13,8538$.

6. (a) Knoeppel, D. W; Shore, S. G. Inorg. Chem. 1996, 35, 1747. (b) Knoeppel, D. W; Shore, S. G. Inorg. Chem. 1996, 35, 5328

7. Chung, J.-H.; Kim, S. H. Bull Korean Chem Soc. 2005, 26, 2075.

8. Lee, S. M.; Kim, J.; Kim, S. H.; Chung, J.-H.; Shore, S. G. Bull. Korean Chem. Soc. 2007, 28, 679.

9. Otwinowski, Z.; Minor, W. In Methods in Enzvnologt; Carter, C. W., Jr., Sweet, R. M., Eds.; Academic Press: New York, 1997; Vol $276(\mathrm{~A}), \mathrm{p} 307$.

10. (a) Blessing, R. H. Acta Cristallogr:, Sect. A 1995, 51, 33. (b) Blessing, R. H. $J$. Appl. Cristallogr: 1997, 30, 421.

11. Mackay, S.; Gilmore, C. J.; Edwards, C.; Tremayne, M.; Stuart, N.; Shankland, K. MaXus: A Computer Program for the Solution and Refinement of Cristal Structures from Diffiaction Data; Lniversity of Glasgow, Scotland; Nonius BV: Delft, The Netherlands and Mac-Science Co. Ltd.: Yokohama, Japan, 1998.

12. Sheldrick, G. M. SHELXZ-97: A Stracture Solution and Refinement Program: Lniversity of Göttingen: Genmany, 1998.

13. Ishiguro, S.; Takahashi, R. Inorg. Chen. 1991, $30,1854$.

14. Knoeppel, D. W.; Liu, I; Meyers, E. A.; Shore, S. G. Inorg. Chen. $1998,17,4828$.

15. Jeffrey, G. A. An Introduction to Hvdrogen Bonding; Oxford Lniversity Press: New York, 1997.

16. Kubas, G. J.; Jones, L. H. Inorg. Chem. 1974, /3, 2186.

17. Nakamodo, K. Infrared and Raman Spectra of Inorganic and Coordination Compounds, Part B, 5th ed; Wiley and Sons: New York, 1997; pp 105-113 and references therein. 